\title{
Glucagon stimulation test to assess growth hormone status in Prader-Willi syndrome
}

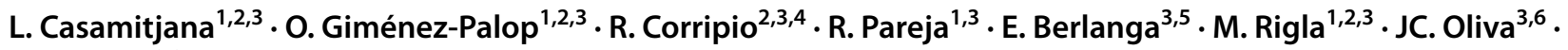 \\ A. Caixàs $\mathbf{s}^{1,2,3}$
}

Received: 14 May 2020 / Accepted: 16 July 2020 / Published online: 27 July 2020

(c) The Author(s) 2020

\begin{abstract}
Purpose Growth hormone deficiency (GHD) must be confirmed before starting treatment in adults with Prader-Willi syndrome (PWS). Most studies use the growth-hormone-releasing hormone plus arginine (GHRH-arginine) test. No data are available on the glucagon stimulation test (GST) in PWS. We compared the utility of fixed-dose (1 mg) GST versus GHRHarginine test in diagnosing GHD.

Methods Adults and late adolescents with PWS underwent both tests on separate days. In the GHRH-arginine test, GHD was defined according to body mass index. In the GST, two cutoffs were analyzed: peak GH concentration $<3 \mathrm{ng} / \mathrm{mL}$ and $<1 \mathrm{ng} /$ $\mathrm{mL}$. For analyses, patients were divided into two groups according to body weight ( $\leq 90 \mathrm{~kg}$ and $>90 \mathrm{~kg}$ ).

Results We analyzed 34 patients: 22 weighing $\leq 90 \mathrm{~kg}$ and 12 weighing $>90 \mathrm{~kg}$. In patients weighing $\leq 90 \mathrm{~kg}$, the two tests were concordant in $16(72.72 \%)$ patients $(k=0.476, p=0.009$ with GST cutoff $<3 \mathrm{ng} / \mathrm{mL}$, and $k=0.450, p=0.035$ with GST cutoff $<1 \mathrm{ng} / \mathrm{mL}$ ). In patients weighing $>90 \mathrm{~kg}$, the two tests were not concordant with GST cutoff $<3 \mathrm{ng} / \mathrm{mL}$, but were concordant in $11(91.6 \%)$ patients $(k=0.833, p=0.003)$ with GST cutoff $<1 \mathrm{ng} / \mathrm{mL}$. GH peaks on the two tests correlated $(r=0.725, p=0.008)$.

Conclusion Fixed-dose ( $1 \mathrm{mg}$ ) GST using a peak GH cutoff of $<3 \mathrm{ng} / \mathrm{mL}$ or $<1 \mathrm{ng} / \mathrm{mL}$ promises to be useful for screening for GHD in adults and late adolescents with PWS. However, in those weighing $>90 \mathrm{~kg}$, the $<1 \mathrm{ng} / \mathrm{mL}$ cutoff seems better. Larger studies are necessary to establish definitive glucagon doses and cutoffs, especially in extremely obese patients.
\end{abstract}

Keywords Prader-Willi · Growth hormone deficiency · Glucagon-stimulation test · GHRH-arginine test

\section{Introduction}

A. Caixàs

acaixas@tauli.cat

1 Endocrinology and Nutrition Department, Hospital Universitari Parc Taulí, C/ Parc Taulí, 1, 08208 Sabadell, Spain

2 Medicine Department, Universitat Autònoma de Barcelona, Bellaterra, Spain

3 Institut d'Investigació i Innovació Parc Taulí (I3PT), Sabadell, Spain

4 Pediatrics Department, Hospital Universitari Parc Taulí, Sabadell, Spain

5 Clinical Laboratory Department, UDIAT, Corporació Sanitària Universitària Parc Taulí, Sabadell, Spain

6 Epidemiology Department, Fundació Parc Taulí, Sabadell, Spain
Prader-Willi syndrome (PWS) is the most common syndromic form of obesity, occurring in approximately one in 10,000-30,000 live births, without sex differences in prevalence. PWS results from the loss of expression of paternal alleles in the PWS region of chromosome 15 [1]. PWS is characterized by hypotonia, high adiposity, low lean mass, hypogonadism, and growth hormone deficiency (GHD) [1, 2]. In children with PWS, it is widely accepted that treatment with growth hormone $(\mathrm{GH})$ can be started without provocative tests to demonstrate GHD. GH treatment usually ends when the growth plates close and longitudinal bone growth finishes. However, after growth and body development, GHD can cause a wide variety of physical and psychological problems that can dramatically worsen quality of life. In early adolescence and adulthood, GH treatment can only be started if GHD is demonstrated by GH provocative tests [3]. 
Depending on the provocative tests and body mass index (BMI)-specific cutoffs used to evaluate GH status in different studies, the prevalence of GHD in PWS varies from 8 to $55 \%[4,5]$. To date, most studies that evaluated GH status in PWS used a standard growth-hormone-releasing hormone (GHRH) plus arginine (GHRH-arginine) test $[6,7]$ or, less frequently, an insulin tolerance test (ITT) [8]. The ITT has traditionally been accepted as the gold standard for assessing adult GHD, but it has potentially serious adverse effects and requires close medical supervision [9]. Furthermore, underlying insulin resistance can prevent normoglycemic and/or hyperglycemic obese patients from achieving the hypoglycemia necessary to stimulate GH secretion [10]. The GHRHarginine test is considered the best alternative, but GHRH is expensive and not widely available in some countries. Moreover, GHRH-arginine might not be the optimal test for diagnosing GHD in PWS as GHRH stimulates both pituitary GH synthesis and release $[11,12]$, whereas arginine potentiates the stimulatory effects of GHRH by inhibiting hypothalamic somatostatin release [13]. These effects can lead to false-normal GH responses in patients with GHD of hypothalamic origin such as in PWS.

The glucagon stimulation test (GST) is an easy-to-perform, safe, inexpensive, and effective means of stimulating GH secretion with relatively few contraindications (e.g., pheochromocytoma or insulinoma) $[14,15]$. Its mechanism of action is unclear, but it is apparently not influenced by hypothalamic deficiency [16]. However, glucagon's effect on GH secretion seems to be weight-dependent [14], and most adults with PWS are obese. There is also no consensus on whether to use a fixed dose or a weight-based dose [17]. Some authors propose two different fixed glucagon doses depending on body weight ( $1 \mathrm{mg}$ for patients weighing $\leq 90 \mathrm{~kg}$ and $1.5 \mathrm{mg}$ for those weighing $>90 \mathrm{~kg}$ ) [14, 16, 17] or on BMI ( $1 \mathrm{mg}$ for patients with BMI $<30 \mathrm{~kg} / \mathrm{m}^{2}$ and 1.5 for those with BMI $\left.\geq 30 \mathrm{~kg} / \mathrm{m}^{2}\right)[15,18]$, whereas others propose weight-based dosing $(0.017 \mathrm{mg} / \mathrm{kg}$ [19] or $0.03 \mathrm{mg} /$ $\mathrm{kg}$ body weight [17]). No prospective data are available about the use of the GST to evaluate GH status in patients with PWS. Thus, we aimed to compare the utility of a single fixed-dose (1 mg) GST versus the GHRH-arginine test for diagnosing GHD in adults and late adolescents with PWS.

\section{Materials and methods}

\section{Patients}

We included all adult and late adolescent patients with PWS treated at our center between January 1, 2016 and January $31,2018(N=34)$.

All subjects underwent cytogenetic analysis. Height was determined by a Harpenden Stadiometer (Holtain Ltd,
Dyfed, UK). Body weight was measured to the nearest $0.1 \mathrm{~kg}$ with standard equipment. Body mass index (BMI) was defined as weight in kilograms divided by the square of height in meters. According to the World Health Organization classification [20], normal weight was defined as BMI $18.5-24.9 \mathrm{~kg} / \mathrm{m}^{2}$, overweight as BMI $25-29.9 \mathrm{~kg} / \mathrm{m}^{2}$, and obese as BMI $\geq 30 \mathrm{~kg} / \mathrm{m}^{2}$.

\section{Endocrine protocol}

All subjects underwent a standard GHRH-arginine test and a standard GST on separate days ranging from 8 to 15 days apart, being randomly assigned to start with one test or the other with a random-number generator [21].

Both tests started at $8 \mathrm{AM}$ after overnight fasting and were done with patients in a recumbent position.

\section{GHRH-arginine test}

A catheter was placed in the antecubital vein; 15 min later $1 \mu \mathrm{g} / \mathrm{kg}$ GHRH $_{1-29}(\mathrm{GHRH}$, Ferring GmbH, Kiel, Germany) was injected as a bolus. In the $30 \mathrm{~min}$ after GHRH administration, $0.5 \mathrm{~g} / \mathrm{kg}$ (maximum dose $30 \mathrm{~g}$ ) L-arginine hydrochloride (Torbay Pharmaceuticals, Paignton, Devon, UK) diluted in $300 \mathrm{cc}$ of saline $0.9 \%$ sodium chloride was infused. Blood samples for $\mathrm{GH}$ determination were drawn at $-15,0,30,45,60,90$, and 120 min after the intravenous bolus of GHRH. GH deficiency was defined as a peak concentration $<11 \mathrm{ng} / \mathrm{mL}$ if BMI $<25 \mathrm{~kg} / \mathrm{m}^{2},<8 \mathrm{ng} / \mathrm{mL}$ if BMI $25-30 \mathrm{~kg} / \mathrm{m}^{2}$, and $<4 \mathrm{ng} / \mathrm{mL}$ if BMI $\geq 30 \mathrm{~kg} / \mathrm{m}^{2}$ [22].

\section{GST}

All subjects received an intramuscular injection of $1 \mathrm{mg}$ of glucagon (Novo-Nordisk, Bagsvaerd, Denmark) in the deltoid muscle. Blood samples for glucose and GH determinations were drawn every $30 \mathrm{~min}$ from baseline until $180 \mathrm{~min}$ [14]. GHD was defined in two ways: according to the classical definition (peak concentration $<3 \mathrm{ng} / \mathrm{mL}$ ) $[14,15]$ and according to the definition recently proposed by Hamrahian et al. [17] (peak concentration $<1 \mathrm{ng} / \mathrm{mL}$ ).

GH concentrations were measured by chemiluminescent immunoassay (LIAISON hGH, Diasorin S.p.A, Saluggia, Italy). The sensitivity was $0.05 \mathrm{ng} / \mathrm{mL}$ and intra-assay coefficients of variation $(\mathrm{CV})$ were $2.26 \%$ at $3.48 \mathrm{ng} / \mathrm{mL}$ and $1.93 \%$ at $17.3 \mathrm{ng} / \mathrm{mL}$. 


\section{Statistical analyses}

Continuous variables are reported as medians and interquartile ranges (IQR). Categorical variables are reported as frequencies and percentages. To assess the concordance between diagnostic tests, we used the Kappa index and its standard error. To compare GH peak concentration between the two tests, we used the Mann -Whitney U test and for multiple comparisons we used the Kruskal-Wallis test. To study the relationship between variables, we used regression analysis. Statistical significance was fixed at $p<0.05$. Because using a single $1 \mathrm{mg}$ dose of glucagon in patients weighing $>90 \mathrm{~kg}$ is not widely accepted, for the purpose of analysis we divided patients into two groups according to body weight ( $\leq 90 \mathrm{~kg}$ and $>90 \mathrm{~kg}$ ). All analyses were done with IBM SPSS Statistics for Windows, version 25.0 (IBM Corp., Armonk, N.Y., USA).

\section{Results}

\section{Patients weighing $\leq 90 \mathrm{~kg}$}

We evaluated 22 patients with PWS who weighed $\leq 90 \mathrm{~kg}$ [18 adults and 4 late adolescents; 5 male and 17 female; median age, 23.5 y (IQR: 19.7-36.2), range 15-47 y; median BMI, $30.7 \mathrm{~kg} / \mathrm{m}^{2}$ (IQR: 24.8-34.0)]. Of these, 5 were normal weight, 5 overweight, and 12 obese, including 1 with $\mathrm{BMI} \geq 40 \mathrm{~kg} / \mathrm{m}^{2}$. Cytogenetic analysis revealed that $14 \mathrm{had}$ microdeletions ( 6 type I, 8 type II), 5 had maternal uniparental disomy, and 3 had imprinting defects. Prior to the study, 15 patients had undergone GH therapy; all had stopped the therapy at least 1 year before enrollment. At the time of the study, 10 patients were undergoing sex steroid replacement therapy. A total of 5 patients had type 2 diabetes ( 2 treated only with oral agents, 2 with oral agents and GLP-1 analogues, and 1 with oral agents and insulin); metabolic control was acceptable (glycosylated hemoglobin $<7 \%$ ). Table 1 reports the characteristics of each patient, peak GH concentrations in the two tests, and whether GHD was diagnosed according to each test and cutoff.

\section{GHRH-arginine test}

According to the established BMI-related cutoffs, 10 $(45.5 \%)$ patients met the criteria for GHD. Of these 10 patients, 4 were overweight and 6 obese; of the 12 that did not meet the criteria for GHD, 5 were normal weight, 1 overweight, and 6 obese. No adverse effects occurred during the test. Median peak GH concentration was $8.19 \mathrm{ng} / \mathrm{mL}$ (IQR: $3.1-14.0 \mathrm{ng} / \mathrm{mL}$ ).

\section{Glucagon-stimulation test}

According to the classical cutoff (peak concentration $<3 \mathrm{ng}$ / $\mathrm{mL}), 16$ (72.7\%) patients met the criterion for GHD. Of these 16 patients, 2 were normal weight, 5 overweight, and 9 obese; of the 6 that did not meet the criterion for GHD, 3 were normal weight and 3 obese. The GST classified all patients weighing $>79.5 \mathrm{~kg}(n=6)$ as GHD.

According to the recently proposed cutoff $(1 \mathrm{ng} / \mathrm{mL}), 10$ (45.5\%) met the criterion for GHD. Of these 10 patients, 1 was normal weight, 1 overweight, and 8 obese; of the 12 that did not meet the criterion for GHD, 4 were normal weight, 4 overweight, and 4 obese.

No adverse effects occurred during the test. In 18 (81.8\%) patients, the concentration of GH peaked between 120 and 180 min after glucagon administration. Median peak GH concentration was $1.15 \mathrm{ng} / \mathrm{mL}$ (IQR: 0.24-3.97 ng/mL).

\section{Concordance between the GST and the GHRH-arginine test}

Using the $<3 \mathrm{ng} / \mathrm{mL}$ cutoff for GST, the two tests were concordant in $16(72.7 \%)$ patients and discordant in $6(27.3 \%)$ ( $k=0.476, p=0.009$ ) (Table 2). Using the $<1 \mathrm{ng} / \mathrm{mL}$ cutoff, the two tests were concordant in $16(72.7 \%)$ patients and discordant in $6(27.3 \%)(k=0.450, p=0.035)$ (Table 3$)$.

\section{Subgroup analyses}

In the 15 patients that underwent GH treatment during childhood, peak GH concentration on the GHRH-arginine test was higher than in those who did not receive GH during childhood [12.5 ng/mL (IQR: 3.58-25.8 ng/mL) vs. $3.10 \mathrm{ng} / \mathrm{mL}$ (IQR: $1.52-6.13 \mathrm{ng} / \mathrm{mL}$ ), respectively, $p=0.009]$. On the GST, GH peaks were similar: [1.32 ng/ mL (IQR: $0.32-4.57 \mathrm{ng} / \mathrm{mL}$ ) for patients with $\mathrm{GH}$ treatment in childhood vs. $1.00 \mathrm{ng} / \mathrm{mL}$ (IQR: $0.18-1.26 \mathrm{ng} / \mathrm{mL}$ ) for those without, $p=0.332$ ]. Those who received GH treatment during childhood were younger [23.0 years (IQR: 19.6-26.7 years) vs. 37.0 years (IQR: 27.3-43.9 years), respectively, $p=0.007]$ and had lower BMI $\left[28.9 \mathrm{~kg} / \mathrm{m}^{2}\right.$ (IQR: $25.9-32.0 \mathrm{~kg} / \mathrm{m}^{2}$ ) vs. $34.3 \mathrm{~kg} / \mathrm{m}^{2}$ (IQR: $30.2-36.2 \mathrm{~kg} /$ $\mathrm{m}^{2}$ ), respectively, $p=0.039$ ].

Regarding the genetic subtype, those with imprinting defects had the lowest peak concentrations of GH on both tests, being significant only for the GST [Deletion type I: $1.29 \mathrm{ng} / \mathrm{mL}$ (IQR: $0.51-5.83 \mathrm{ng} / \mathrm{mL}$ ), Deletion type II: $1.82 \mathrm{ng} / \mathrm{mL}$ (IQR: $0.70-7.00 \mathrm{ng} / \mathrm{mL}$ ), Imprinting defect: $0.10 \mathrm{ng} / \mathrm{mL}$ (IQR:0.05-not calculable $\mathrm{ng} / \mathrm{mL}$ ), Maternal uniparental disomy: $1.24 \mathrm{ng} / \mathrm{mL}$ (IQR: $0.20-6.84 \mathrm{ng} / \mathrm{mL}$ ), 


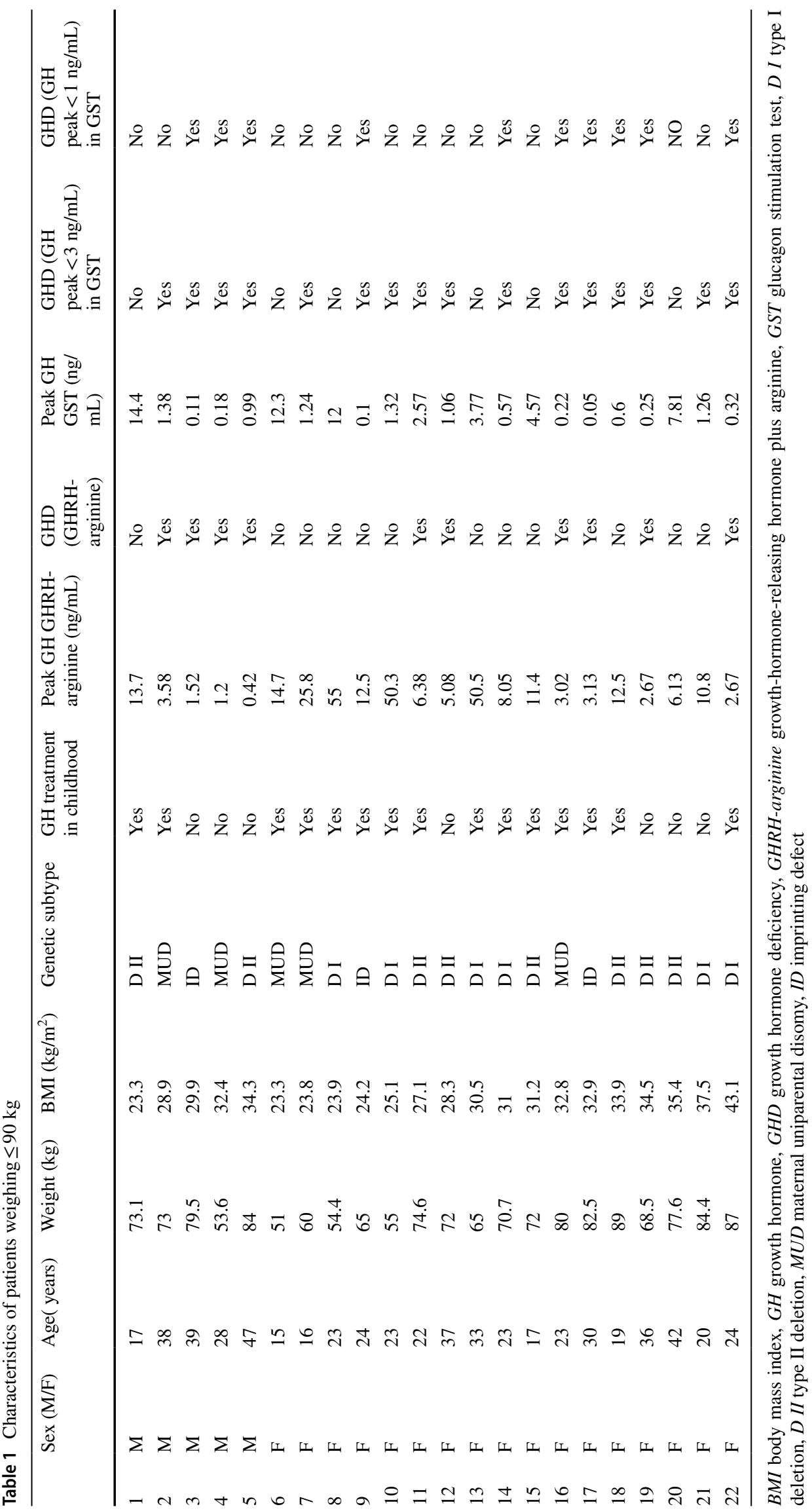


Table 2 Contingency table in patients weighing $\leq 90 \mathrm{~kg} \quad(n=22)$. growth hormone deficiency (GHD) according to the glucagon stimulation test (GST) using peak growth hormone concentration $<3 \mathrm{ng} /$ $\mathrm{mL}$ as the cutoff versus according to the growth-hormone-releasing hormone (GHRH)-arginine test

\begin{tabular}{lll}
\hline $\begin{array}{l}\text { GHD with GST (GH } \\
\text { peak }<3 \mathrm{ng} / \mathrm{mL}), n(\%)\end{array}$ & $\begin{array}{l}\text { GHD with the GHRH-arginine } \\
\text { test } n(\%)\end{array}$ \\
\cline { 2 - 3 } & No & Yes \\
\hline No & $6(100.0 \%)$ & $0(0.0 \%)$ \\
Yes & $6(37.5 \%)$ & $10(45.5 \%)$ \\
\hline
\end{tabular}

Table 3 Contingency table in patients weighing $\leq 90 \mathrm{~kg} \quad(n=22)$. growth hormone deficiency (GHD) according to the glucagon stimulation test (GST) using peak growth hormone concentration $<1 \mathrm{ng} /$ $\mathrm{mL}$ as the cutoff versus according to the growth-hormone-releasing hormone (GHRH)-arginine test

\begin{tabular}{lll}
\hline $\begin{array}{l}\text { GHD with GST }(\mathrm{GH} \text { peak }<1 \mathrm{ng} / \\
\mathrm{mL}(\%)\end{array}$ & $\begin{array}{l}\text { GHD with the GHRH-arginine } \\
\text { test } n(\%)\end{array}$ \\
\cline { 2 - 3 } & No & Yes \\
\hline No & $9(75.0 \%)$ & $3(25.0 \%)$ \\
Yes & $3(30.0 \%)$ & $7(70.0 \%)$
\end{tabular}

$\mathrm{p}=0.048]$. This significance did not disappear after adjustment for age, weight, or BMI.

Peak GH was higher in females than in males on the GHRH-arginine test [10.8 ng/mL (IQR: 4.11-20.3 ng/ $\mathrm{mL}$ ) vs. $2.10 \mathrm{ng} / \mathrm{mL}$ (IQR: $1.36-8.64 \mathrm{ng} / \mathrm{mL}$ ), respectively, $p=0.039)]$, but not on the GST $[1.24 \mathrm{ng} / \mathrm{mL}$ (IQR: $0.29-4.17 \mathrm{ng} / \mathrm{mL}$ ) in females vs. $1.0 \mathrm{ng} / \mathrm{mL}$ (IQR: $0.15-7.89 \mathrm{ng} / \mathrm{mL}$ ) in males, $p=0.820)$ ].

There were no differences in GH response on either test between patients treated with sex steroids versus those not treated with sex steroids in the whole group or separated by sex (data not shown).

\section{Regression analysis}

Peak concentrations of GH observed on the two tests did not correlate $(r=0.330, p=0.134)$. GH peak on the GHRHarginine test correlated negatively with BMI $(r=-0.465$, $p=0.029)$ and weight $(r=-0.562, p=0.06)$, but not with age. Peak GH on the GST correlated negatively with BMI $(r=-0.469, p=0.028)$ (Fig. 1), but not with age $(r=0.293$, $p=0.186)$ or with weight $(r=0.368, p=0.092)$.

\section{Patients weighing $>90 \mathrm{~kg}$}

We evaluated 12 patients with PWS who weighed $>90 \mathrm{~kg}$ [12 adults; 7 male and 5 female; median age, 26 y (IQR: 19.0-32.3), range 18-51 y; median BMI, $41.0 \mathrm{~kg} / \mathrm{m}^{2}$ (IQR: $34.9-49.2)]$. All were obese, 7 with $B M I \geq 40 \mathrm{~kg} / \mathrm{m}^{2}$. Cytogenetic analysis revealed that 10 had microdeletions (5 type I, 4 type II, and 1 atypical BP2-BP4 microdeletion) and 2 had maternal uniparental disomy. Prior to the study, 4 patients had undergone GH therapy; all had stopped the therapy at least 1 year before enrollment. At the time of the study, 8 patients were undergoing sex steroid replacement therapy. Two patients had type 2 diabetes ( 1 treated with oral agents, GLP-1 analogues, and insulin, and the other with oral agents and insulin); metabolic control was acceptable (glycosylated hemoglobin $<7 \%$ ). Table 4 reports the characteristics of each patient, peak GH concentrations in the two tests, and whether GHD was diagnosed according to each test and cutoff.

\section{GHRH-arginine test}

According to the established BMI-related cutoffs, 7 (58.3\%) patients met the criteria for GHD. Median peak GH concentration was $2.90 \mathrm{ng} / \mathrm{mL}$ (IQR: $1.38-6.47 \mathrm{ng} / \mathrm{mL}$ ).
Fig. 1 Correlation between peak growth hormone $(\mathrm{GH})$ concentration and body mass index (BMI) on the glucagon-stimulation test (GST) in patients weighing $\leq 90 \mathrm{~kg}$. Spearman correlation test, $r=-0.469$, $p=0.028$

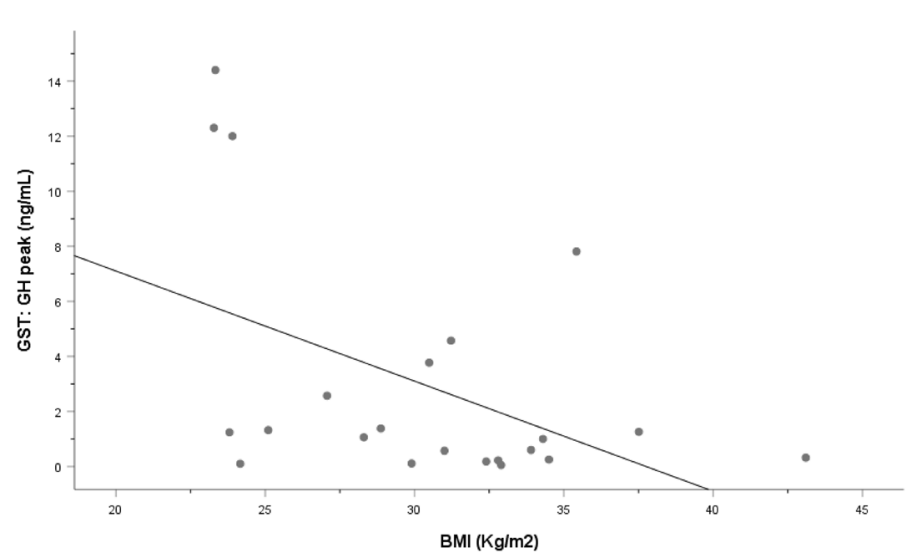




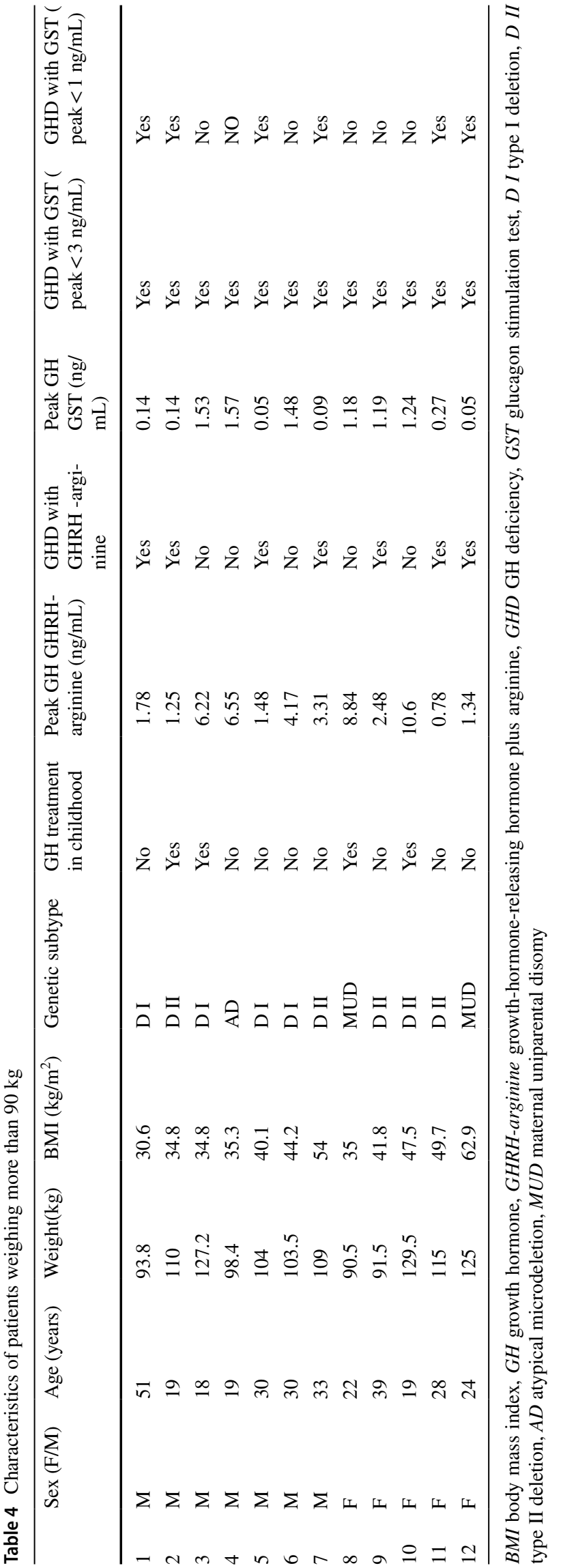

Table 5 Contingency table in patients weighing $>90 \mathrm{~kg} \quad(n=12)$ : growth hormone deficiency (GHD) according to the glucagon stimulation test (GST) using peak growth hormone concentration $<1 \mathrm{ng} /$ $\mathrm{mL}$ as the cutoff versus according to the growth-hormone-releasing hormone $(\mathrm{GHRH})$-arginine test

\begin{tabular}{lll}
\hline $\begin{array}{l}\text { GHD with GST ( GH } \\
\text { peak }<1 \mathrm{ng} / \mathrm{mL})\end{array}$ & $\begin{array}{l}\text { GHD with the GHRH-arginine test } \\
n(\%)\end{array}$ \\
\cline { 2 - 3 } & No & Yes \\
\hline No & $5(83.3 \%)$ & $1(16.7 \%)$ \\
Yes & $0(0.0 \%)$ & $6(100.0 \%)$ \\
\hline
\end{tabular}

\section{Glucagon-stimulation test}

According to the classical cutoff (peak concentration $<3 \mathrm{ng}$ / $\mathrm{mL}$ ), all patients, met the criterion for GHD.

According to the recently proposed cutoff (peak concentration $<1 \mathrm{ng} / \mathrm{mL}), 6(50 \%)$ met the criterion for GHD. Of these 6 patients, 4 had BMI $>40 \mathrm{~kg} / \mathrm{m}^{2}$.

No adverse effects occurred during the test. In 10 (83.3\%) patients, the concentration of GH peaked between 120 and 180 min after glucagon administration. Median peak GH concentration was $0.73 \mathrm{ng} / \mathrm{mL}$ (IQR: $0.10-1.42 \mathrm{ng} / \mathrm{mL}$ ).

\section{Concordance between the GST and the GHRH-arginine test}

Using the $<3 \mathrm{ng} / \mathrm{mL}$ cutoff, because all patients met the criterion for GHD on the GST, the two tests were not concordant $(k=0)$.

Using the $<1 \mathrm{ng} / \mathrm{mL}$ cutoff, the two tests were concordant in $11(91.7 \%)$ patients $(k=0.833, p=0.003)$ (Table 5).

\section{Regression analysis}

There was a good correlation between peak GH concentrations on the two tests $(r=0.725, p=0.008)$ (Fig. 2). No correlations were observed between peak GH and BMI, weight, or age on either test.

\section{Discussion}

We aimed to evaluate the utility of a GST using a fixeddose $(1 \mathrm{mg})$ of glucagon administered intramuscularly in diagnosing GHD in adults and late adolescents with PWS by comparing the results with those achieved with the GHRHarginine test. In patients weighing $\leq 90 \mathrm{~kg}$, the GST diagnosis was concordant with the GHRH-arginine test diagnosis, regardless of whether the peak GH cutoff was $<3 \mathrm{ng} / \mathrm{mL}$ or $<1 \mathrm{ng} / \mathrm{mL}$. However, in patients weighing $>90 \mathrm{~kg}$, only the $<1 \mathrm{ng} / \mathrm{mL}$ peak GH cutoff had good concordance with the GHRH-arginine test. These findings suggest that GST could be used in cases where other, more sophisticated tests 
Fig. 2 Correlation between peak growth hormone $(\mathrm{GH})$ concentration on the growthhormone-releasing hormone (GHRH)-arginine test and on the glucagon-stimulation test (GST) in patients weighing $>90 \mathrm{~kg}$. Spearman correlation test, $r=0.725, p=0.008$

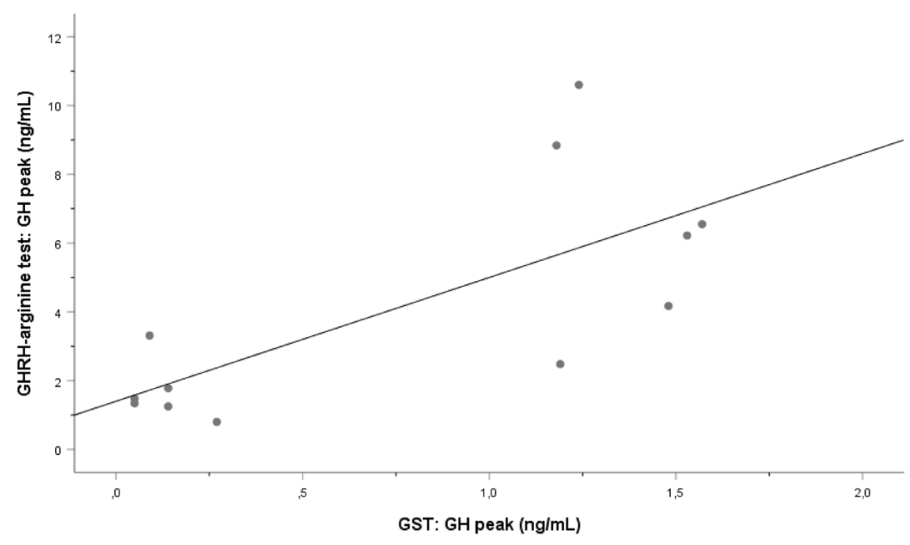

those with BMI $>40 \mathrm{~kg} / \mathrm{m}^{2}[25,26]$. In our cohort, all subjects weighing $>79.5 \mathrm{~kg}(n=18)$ failed to achieve peak $\mathrm{GH}$ concentrations $>3 \mathrm{ng} / \mathrm{mL}$ in the GST. However, in those weighing $>90 \mathrm{~kg}$, defining GHD as a peak GH concentration $<1 \mathrm{ng} / \mathrm{mL}$ yielded results more concordant with those of the GHRH-arginine test and peak GH in the two tests showed a good correlation.

In the analysis of subgroups of the patients weighing $\leq 90 \mathrm{~kg}$, patients who received $\mathrm{GH}$ treatment during childhood had a higher GH peak on the GHRH-arginine test, probably because this group was younger and had lower BMI than the group not treated with GH during childhood.

The lowest $\mathrm{GH}$ peak found in the imprinting defect genetic subtype, even after adjusting for age and BMI, must be interpreted with caution given the lack of power due to the sample size. However, other authors have also reported that the pattern of GH secretion varied by genetic subtype, with higher $\mathrm{GH}$ responses in typical deletion subjects than in patients with disomy [27]. Further studies are needed to elucidate the significance of this finding.

The higher $\mathrm{GH}$ peak on the GHRH-arginine test in females than in males could be related to an estrogenic effect. Several earlier studies have shown that estrogens can enhance the $\mathrm{GH}$ response to most stimuli, such as hypoglycemia and arginine, in men and in premenopausal and postmenopausal women [28]. By contrast, no sex-based difference in $\mathrm{GH}$ response to glucagon was observed in this study or in others [29, 30], and exogenous estrogen administration is ineffective in enhancing the $\mathrm{GH}$ response to glucagon in men [29].

The mechanisms by which glucagon stimulates $\mathrm{GH}$ secretion remain unclear [9]. It seems that peak GH concentrations do not directly depend on glycemic levels [31]. One possible mechanism could be that breakdown of glucagon in the muscles produces a peptidyl fragment that promotes the release of GH [19]. Additionally, glucagon induces norepinephrine secretion, which might stimulate the release of GH via $\alpha$-receptors [16]; this mechanism could be of great 
interest in PWS because patients with PWS have underlying autonomic dysfunction [32].

The route of glucagon administration may also be important in the release of GH. Intravenous glucagon causes less GH release than both intramuscular and subcutaneous glucagon [33]. We chose the intramuscular route because it has been suggested to be more reliable and effective than the subcutaneous route [30]. However, new routes, such as intranasal glucagon, recently approved by FDA [34] to treat hypoglycemia, might also prove effective, although to our knowledge there is insufficient information about its effectiveness in provoking the release of GH.

- Our study has several limitations. First, we compared the results of the GST against GHRH-arginine test rather than against the gold standard (ITT). However, the ITT has serious drawbacks in PWS patients, and the GHRHarginine test is more widely used. Second, our analyses may have been underpowered to detect small effects, given the relatively small sample size including patients with a wide range of BMI. The number of patients weighing $>90 \mathrm{~kg}$ was low $(n=12)$, and they received $1 \mathrm{mg}$ glucagon rather than the $1.5 \mathrm{mg}$ recommended by other authors. Nevertheless, using the cutoff $<1 \mathrm{ng} / \mathrm{mL}$, we obtained good concordance between the two tests in this group of patients. Finally, we did not take glycemic status into account. Whether glucose levels can interfere with the response in the GST is controversial. Higher blood glucose levels (whether fasting or peak and nadir) during the GST have been associated with lower peak GH responses in some studies [25, 35]; however, other authors consider that blood glucose levels do not impair glucagon-induced GH release [29, 36].

In conclusion, a fixed-dose (1 mg) GST using a peak GH cutoff of $<3 \mathrm{ng} / \mathrm{mL}$ or $<1 \mathrm{ng} / \mathrm{mL}$ seems useful for screening for GHD in adults and late adolescents with PWS. However, in those weighing $>90 \mathrm{~kg}$, the $<1 \mathrm{ng} / \mathrm{mL}$ cutoff is more suitable. Larger studies are necessary to corroborate our findings and establish definitive glucagon doses and cutoffs, especially in patients with extreme obesity or glucose intolerance.

Acknowledgements We thank the Associació Catalana de Síndrome de Prader-Willi for their crowdfunding and all the patients and their families for kindly agreeing to participate.

Author contributions LC, OG-P, and AC designed the study, recruited the patients, and wrote the first draft of the manuscript. MR, RC, and $\mathrm{AC}$ contributed to additional versions of the manuscript. RP, LC, AC, and OG-P did all the tests. EB did the laboratory work and JCO analyzed the data.

Funding This study was supported in part by the Fondo de Investigación Sanitaria del Instituto Carlos III-Fondo Europeo de Desarrollo
Regional (Grant PI-18/00734). This work was also supported by a grant from Pfizer (2015/594).

\section{Compliance with ethical standards}

Conflicts of interest The authors have no conflicts of interest.

Ethics approval The study complied with all provisions in the Declaration of Helsinki and was approved by the local ethics committee (Comitè d'Ètica d'Investigació amb. medicaments (CEIm) del Parc Taulí).

Consent to participate All patients agreed to participate after being informed together with their parents or caregivers. Their legal guardians (usually theirparents) signed the informed consent before enrollment.

Consent for publication All authors agree to publish these results.

Open Access This article is licensed under a Creative Commons Attribution 4.0 International License, which permits use, sharing, adaptation, distribution and reproduction in any medium or format, as long as you give appropriate credit to the original author(s) and the source, provide a link to the Creative Commons licence, and indicate if changes were made. The images or other third party material in this article are included in the article's Creative Commons licence, unless indicated otherwise in a credit line to the material. If material is not included in the article's Creative Commons licence and your intended use is not permitted by statutory regulation or exceeds the permitted use, you will need to obtain permission directly from the copyright holder. To view a copy of this licence, visit http://creativecommons.org/licenses/by/4.0/.

\section{References}

1. Cassidy SB, Schwartz S, Miller JL, Driscoll DJ (2012) PraderWilli syndrome. Genet Med 14:10-26

2. Angulo MA, Butler MG, Cataletto ME (2015) Prader-Willi syndrome: a review of clinical, genetic, and endocrine findings. $J$ Endocrinol Invest 38:1249-1263

3. Deal CL, Tony M, Hoÿbye C et al (2013) Growth hormone research society workshop summary: consensus guidelines for recombinant human growth hormone therapy in Prader-Willi syndrome. J Clin Endocrinol Metab 98(6):E1072-1087

4. Moix Gil E, Giménez-Palop O, Caixàs A (2018) Treatment with growth hormone in the Prader-Willi syndrome. Endocrinol Diabetes Nutr 65:229-236

5. Grugni G, Sartorio A, Crinò A (2016) Growth hormone therapy for Prader-Willi syndrome: challenges and solutions. Ther Clin Risk Manag 2(12):873-881

6. Marostica E, Grugni G, De Nicolao G et al (2013) The GHRH+arginine stimulated pituitary GH secretion in children and adults with Prader-Willi syndrome shows age- and BMIdependent and genotype-related differences. Growth Horm IGF Res 23:261-266

7. Grugni G, Marzullo P, Ragusa L et al (2006) Impairment of GH responsiveness to combined $\mathrm{GH}$-releasing hormone and arginine administration in adult patients with Prader-Willi syndrome. Clin Endocrinol (Oxf) 65:492-499

8. Beauloye V, Dhondt K, Buysse W et al (2015) Evaluation of the hypothalamic-pituitary-adrenal axis and its relationship with central respiratory dysfunction in children with Prader-Willi 
syndrome rare endocrinological diseases. Orphanet J Rare Dis 10:4-11

9. Yuen KCJ, Tritos NA, Samson SL et al (2016) American association of clinical endocrinologists and American college of endocrinology disease state clinical review: update on growth hormone stimulation testing and proposed revised cut-point for the glucagon stimulation test in the diagnosis of adult. Endocr Pract 22:1235-1244

10. Lee P, Greenfield JR, Ho KKY (2009) Factors determining inadequate hypoglycaemia during insulin tolerance testing (ITT) after pituitary surgery. Clin Endocrinol (Oxf) 71(1):82-85

11. Barinaga M, Bilezikjian LM, Vale WW et al (1985) Independent effects of growth hormone releasing factor on growth hormone release and gene transcription. Nature 314:279-281

12. Donze SH, Damen L, van der AlfenVelden JAEM et al (2019) Prevalence of growth hormone $(\mathrm{GH})$ deficiency in previously $\mathrm{GH}-$ treated young adults with Prader-Willi syndrome. Clin Endocrinol (Oxf) 91(1):118-123

13. Alba-Roth J, Müller OA, Schopohl J, Von Werder K (1988) Arginine stimulates growth hormone secretion by suppressing endogenous somatostatin secretion. J Clin Endocrinol Metab 67(6):1186-1189

14. Gómez JM, Espadero RM, Escobar-Jiménez F et al (2002) Growth hormone release after glucagon as a reliable test of growth hormone assessment in adults. Clin Endocrinol (Oxf) 56:329-334

15. Conceição FL, da Costa e Silva A, Leal Costa AJ, Vaisman M (2003) Glucagon stimulation test for the diagnosis of GH deficiency in adults. J Endocrinol Invest 26:1065-1070

16. Leong KS, Walker AB, Martin I et al (2001) An audit of 500 subcutaneous glucagon stimulation tests to assess growth hormone and ACTH secretion in patients with hypothalamic-pituitary disease. Clin Endocrinol (Oxf) 54:463-468

17. Hamrahian AH, Yuen KCJ, Gordon MB et al (2016) Revised GH and cortisol cut-points for the glucagon stimulation test in the evaluation of GH and hypothalamic-pituitary-adrenal axes in adults: results from a prospective randomized multicenter study. Pituitary 19:332-341

18. Lin T, Tucci JR (1974) Provocative tests of growth hormone release. A comparison of results with seven stimuli. Ann Intern Med 80(4):464-469

19. Arvat E, Maccagno B, Ramunni J et al (2000) Interaction between glucagon and Hexarelin, a peptidyl GH secretagogue, on somatotroph and corticotroph secretion in humans. Eur J Endocrinol 143:601-606

20. https://www.euro.who.int/en/health-topics/disease-prevention/ nutrition/a-healthy-lifestyle/body-mass-index-bmi. Last accessed 23 June 2020

21. Domenech J (1981) Tablas de Estadística, 4th edn. Herder, Barcelona

22. Corneli G, Di Somma C, Baldelli R et al (2005) The cut-off limits of the $\mathrm{GH}$ response to $\mathrm{GH}$-releasing hormone-arginine test related to body mass index. Eur J Endocrinol 153:257-264
23. Tavares ABW, Seixas-da-Silva IA, Silvestre DHS et al (2015) Potential risks of glucagon stimulation test in elderly people. Growth Horm IGF Res 25:53-56

24. Cook DM, Yuen KCJ, Biller BMK et al (2009) American Association of Clinical Endocrinologists medical guidelines for clinical practice for growth hormone use in growth hormone-deficient adults and transition patients - 2009 update. Endocr Pract 15:1-29

25. Yuen KCJ, Biller BMK, Katznelson L et al (2013) Clinical characteristics, timing of peak responses and safety aspects of two dosing regimens of the glucagon stimulation test in evaluating growth hormone and cortisol secretion in adults. Pituitary 16:220-230. https://doi.org/10.1007/s11102-012-0407-7

26. Toogood A, Brabant G, Maiter D et al (2012) Similar clinical features among patients with severe adult growth hormone deficiency diagnosed with insulin tolerance test or arginine or glucagon stimulation tests. Endocr Pract 18:325-334

27. Grugni G, Giardino D, Crinò A et al (2011) Growth hormone secretion among adult patients with Prader-Willi syndrome due to different genetic subtypes. J Endocrinol Invest 34:493-497

28. Wiedemann E (1981) Adrenal and gonadal steroids. In: Daughaday WH (ed) Endocrine control of growth. Elsevier Ltd, New York, pp 67-119

29. Mitchel ML, Byrne MJ, Sanchez Y, Sawin CT (1970) Detection of growth-hormone deficiency. N Eng J Med 5:539-541

30. Rao RH, Spathis GS (1987) Intramuscular glucagon as a provocative stimulus for the assessment of pituitary function: growth hormone and cortisol responses. Metabolism 36(7):658-663

31. Giuffrida FMA, Berger K, Monte L et al (2009) Relationship between $\mathrm{GH}$ response and glycemic fluctuations in the glucagon stimulation test. Growth Horm IGF Res 19:77-81

32. DiMario FJ, Dunham B, Burleson JA et al (1994) An evaluation of autonomic nervous system function in patients with Prader-Willi syndrome. Pediatrics 93:76-81

33. Cain JP, Williams GH, Dluhy RG (1970) Glucagon stimulation of human growth hormone. J Clin Endocrinol Metab 31:222-224

34. https://www.fda.gov/news-events/press-announcements/fda-appro ves-first-treatment-severe-hypoglycemia-can-be-administeredwithout-injection. Last accessed 23 June 2020

35. Wilson JR, Utz AL, Devin JK (2016) Effects of gender, body weight, and blood glucose dynamics on the growth hormone response to the glucagon stimulation test in patients with pituitary disease. Growth Horm IGF Res 26:24-31. https://doi. org/10.1016/j.ghir.2015.12.005

36. Spathis GS, Bloom SR, Jeffcooate J (1974) Subcutaneus glucagon as a test of the ability of the pituitary to secrete GH and ACTH. Clin Endocrinol (Oxf) 3:175-186

Publisher's Note Springer Nature remains neutral with regard to jurisdictional claims in published maps and institutional affiliations. 